\title{
The Effectiveness of Inquiry-Based Learning Module to Improve the Cognitive Learning Outcomes
}

\author{
$1^{\text {st }}$ Dewi Anjani \\ Master Program of Science Education, \\ Sebelas Maret University \\ corresponding author: \\ wie.anjani@gmail.com
}

\author{
$2^{\text {nd }}$ Suciati \\ Faculty of Teacher Training and \\ Education, Sebelas Maret University \\ suciati@fkip.uns.ac.id
}

\author{
$3^{\text {rd }}$ Maridi \\ Faculty of Teacher Training and \\ Education, Sebelas Maret University \\ maridi@staff.uns.ac.id
}

\begin{abstract}
The needs of the 21st century in education need the creating of young people to have life skills. The life skills can be trained through the learning process and identified through student learning outcomes. Learning outcomes are one of the factors in successful learning. Therefore, a solution is needed to optimize student learning outcomes in the learning process by using the teaching material in the form of the module. The objective of this research is to know the effectiveness of inquirybased learning module to improve learning outcomes. This research was conducted in one of high school in Surakarta, Indonesia. The research method is quasi-experiment, used pretest and posttest design by using two randomly selected classes those were experimental class used an inquiry-based learning module and control one used modules made by biology teachers in Surakarta. The results showed that there were significant differences of learning outcomes between the control and the experimental classes based on the independent samples t-test test results, also seen with the n-gain scores that obtained at 0.390 (middle) in the control class and 0.749 (high) in the experimental class. Based on the research result, it can be concluded that an inquiry-based learning module is effective to improve the learning outcomes.
\end{abstract}

Keywords-module, inquiry-based learning, learning outcomes

\section{INTRODUCTION}

The rapid development of science and technology in the $21^{\text {st }}$ century has an impact on all aspects of life, including in education [1]. In education, especially science education, they ensure their competitiveness with other nations in the era of globalization [2]. The needs of the $21^{\text {st }}$ century in education, especially science education, need to continue to create young people to have life skills [3]. Life skills can be trained through the learning process and identified through student learning outcomes.

Student learning outcomes based on the data of the Program for International Student Assessment showed that Indonesian students in the field of science are ranked 60 of 66 countries [4]. In the results of the International Mathematics and Science Study Trends stated that Indonesian students in the field of science and mathematics are ranked 30 of 42 countries [5]. Based on these results, the learning outcomes of students in Indonesia especially in the field of science have not gone well.

Several factors such as internal factors influence the low learning outcomes are factors that exist in individual students who are studying, and external factors are factors that exist outside the individual self of students such as less interest in learning and motivation [6]. That education affects both internal factors and external factors to student's life and learning outcomes [7]. Learning outcomes are the overall efficiency and outcomes achieved through the learning process at the school expressed by the number or grade based on the test [8]. The result of need analysis in one of the State Senior High Schools in Surakarta, Indonesia shows the low learning outcomes in the field of biology with an average score of $71.85 \%$ which means it is still below the minimum mastery criteria. Based on the national exam results data indicated that the material of the excretory system for three consecutive years was $46.00 \%$ (2014), 50.50\% (2015) and $46.32 \%$ (2016).

The results of the analysis in the book and module, which is made by the biology teacher in Surakarta, used in the school show that the activities in the learning have not led to the scientific approach. Moreover, the question of evaluation has an average level of difficulty at the level of C1-C3 so that students' thinking ability to is less to train in answering the question. It is an obstacle experienced by students who are doing the learning activities so that student learning outcomes are low [9]. Based on the facts in the field, a solution is needed to optimize student learning outcomes in the learning process that requires a tool in learning, one of which is learning resources in the form of teaching materials that is the module.

The module is one of the most comprehensive and systematic teaching materials in which it contains a set of planned and designed learning experiences to enable students to master specific learning objectives [10]. The modules are arranged systematically referring to the objectives of learning or competence that are clear and measurable and include learning objectives/competencies, materials, and activities to achieve the objectives and tools of evaluation towards the achievement of learning objectives [11]. A module with a scientific approach involves a module with a scientific learning model. The learning process with the scientific approach to the ideal subjects is implemented through a model with activities that train students to make inquiry [12]. Following the Curriculum 2013 students are expected to have a much better competence, skills, and knowledge through a scientific approach [13]. One of the proper learning model to 
apply is through inquiry-based learning model which contains syntax from Pedaste et al. [14] that is orientation, conceptualization, investigation, conclusion, and discussion. The model of inquiry-based learning is learning that refers to the activities of students who develop knowledge and understanding of scientific ideas as well as an understanding of how scientists study nature [15]. The inquiry-based learning model could be trained in improving critical thinking skills through teaching and learning as well as developing the knowledge, skills and assessing the learning outcomes needed to achieve success in the future [16].

Student learning outcomes can be taught through an inquiry-based learning model following the Curriculum 2013 that learning using a scientific approach is a learning that is designed in such a way that students are actively involved and participate in learning (Permendikbud number 65 of 2013). Efforts for active participation of students in the learning process following the Curriculum 2013, researchers create a product inquiry-based learning module on the material excretory system. Developed modules are expected to support the learning process, guiding students to conduct inquiring activities through structured activities in the module and to improve student learning outcomes following the demands of the 21 st century.

\section{METHODS}

This research used a quasi-experiment method. The study was conducted in State Senior High School 8 in Surakarta, Indonesia. The objects of this research were two classes (class 11) which consist of 27 students in each class. Classes are randomly selected by conducting prerequisite tests with normality and homogeneity tests. The research procedure was carried out by adapting Borg \& Gall's development model, with ten steps modified to nine steps by not performing the tenth stage due to time and cost considerations.

The data were collected using test techniques for student cognitive learning outcomes. Problem test was given to determine whether it is valid or not to use. The previous problem has been validated by experts and tested in the State Senior High School 5 Surakarta on 20 students of the $12^{\text {th }}$ grades with the reason they have studied the excretory system material. The question is a multiple choice that consists of 30 questions. For evaluation of test questions, correct and wrong answers are given a score of 1 and 0 . The result then tested with a validity test, and reliability test is presented in Table 1 below.

Table 1 . The Result of Validity and Reliability Tests

\begin{tabular}{llcc}
\multicolumn{4}{c}{ Validity Test } \\
\hline \multirow{4}{*}{ Cases } & Valid & N & \% \\
& Excluded & 20 & 100.0 \\
& Total & 0 & .0 \\
& & 20 & 100.0 \\
\hline
\end{tabular}

Reliability Test

\begin{tabular}{cc}
\hline $\begin{array}{c}\text { Cronbach's } \\
\text { Alpha }\end{array}$ & N of Items \\
\hline 0.931 & 30 \\
\hline
\end{tabular}

The result of test analysis on validity and reliability tests stated that $\mathrm{N}=$ number of students get $\mathrm{r}$ table $=0.004$ concluded that the number 30 valid and reliable. It means that the extent of accuracy and accuracy of a measuring instrument in performing the function of measurement (validity) while (Reliability) to determine the consistency of the measuring instrument, whether the measuring device used is reliable and remains consistent if the measurement is repeated [17].

At the level of students' achievement is assessed through an inquiry-based learning module developed by the researcher. In the module activity using inquiry-based learning syntax by Pedaste et al. [18] which consists of orientation, conceptualization, investigation, conclusion, and discussion. The experts validated the inquiry-based learning module on excretory system material to improve student learning outcomes the experts, education practitioners, and students and show valid results based on validation scores by validators. The results of each validator are presented in Table 2 below.

Table 2. The Validation Result of Inquiry-Based Learning Module

\begin{tabular}{ccc}
\hline Expert & Average & Criteria \\
\hline Linguist & 4.00 & Very good \\
Material & 3.78 & Very good \\
Development & 3.72 & Very good \\
Learning Device & 3.71 & Very good \\
Education Practitioners & 3.76 & Very good \\
Students & 3.50 & Good \\
\hline
\end{tabular}

Based on the module validation result the average score on linguists get the highest score of 4.00; The material expert gets score 3.78; Development expert gets score 3.72; The learning device expert gets score 3.71; Education practitioners get 3.76; students get the smallest score of 3.50 but still categorized well. From these results, it can be concluded that the inquiry-based learning module on excretory system material to improve student learning outcomes is categorized very good, valid and feasible to use in experimental class.

To know the difference between pretest and posttest scores, we have obtained from the control class and experiment class, data analysis was done. In the data analysis, before and after learning was assessed using independent samples t-test to see the experiment class between pretest and posttest was analyzed with $\mathrm{N}$-gain. The $\mathrm{N}$-gain value criterion is presented potential differences between the experimental classes taught by using inquiry-based learning modules, and control classes were taught using modules made by biology teachers in Surakarta. After the learning 
process, the difference between the control class and in Table 3 below.

Table 3. Criteria of N-gain Score and Interpretation

\begin{tabular}{cc}
\hline Gain Index & Interpretation \\
\hline $\mathrm{g}>0,7$ & High \\
$0,3<\mathrm{g} \leq 0,7$ & Middle \\
$\mathrm{g} \leq 0,3$ & Low \\
\hline
\end{tabular}

\section{RESULT}

The inquiry-based learning module was developed using the five-step syntax of inquiry-based learning model learning to improve student learning outcomes. The module is divided into three chapters of excretory system material, namely the excretory system of the lungs, skin, liver, and kidneys. In each chapter is divided into four indicators of knowledge that mention the functions of the lungs, skin, liver, and kidneys. The module is divided into three activities: the first activity, the lung excretory system describes the function, the organs involved, the mechanism and the disorder, the second encounter, the skin excretory system describes the function, structure, mechanism, and disorder, And the third encounter, the liver, and kidney excretory system describes the functions, the organs involved, the mechanisms and disorders/abnormalities.

The percentage of learning outcome scores in the control class and the experimental class during the learning process can be presented in Fig. 1 .

The first meeting, on the lung excretory system material scored $73.33 \%$ in the experimental class and the score of $60.74 \%$ in the control class. The second meeting, on skin excretory system material got score $81,48 \%$ in experiment class and score $71,85 \%$ in control class. The third meeting, on the material of the liver and kidney excretory system, obtained a score of $91.11 \%$ in the experimental class and $76.29 \%$ in the control class. It can be seen from Fig. 1. that the score of the students' learning outcomes for each meeting in both the experimental class and the control class always has an increase.

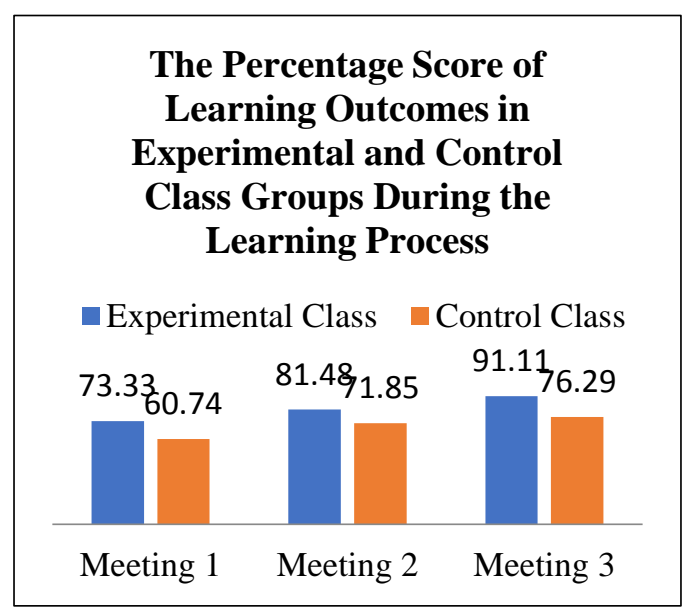

Fig. 1. The Percentage Score of Learning Outcomes in Experimental and Control Class Groups During the Learning Process

Note:

Meeting 1 : Learning materials on the lung excretory system describe the functions, the organs involved, the mechanisms and the disorders / abnormalities.

Meeting 2 : Learning materials on the skin excretory system describe the functions, structures, mechanisms, and disorders/abnormalities

Meeting 3 : Learning materials on the liver and kidney excretory systems describe the functions, the organs involved, the mechanisms and the disorders / abnormalities.

The results of the pretest and posttest descriptive analysis for student learning outcomes in control and experimental classes are presented in Table 4 below.

Table 4. The Result of Pretest and Posttest in Control and Experimental Classes

\begin{tabular}{clcccc}
\hline $\begin{array}{c}\text { Class } \\
\text { Group }\end{array}$ & Score & Range & $\begin{array}{c}\text { Minim } \\
\text { um } \\
\text { Score }\end{array}$ & $\begin{array}{c}\text { Maxim } \\
\text { um } \\
\text { Scor }\end{array}$ & Mean \\
\hline Control & Pretest & 30 & 30 & 60 & 46.28 \\
& Posttest & 40 & 40 & 80 & 66.72 \\
Experim & Pretest & 30 & 30 & 60 & 49.36 \\
ental & Posttest & 40 & 60 & 100 & 85.76 \\
\hline
\end{tabular}

Table 5. The Result of N-gain in Control and Experimental Classes

\begin{tabular}{|c|c|c|}
\hline Min & Max & Average \\
\hline 0.07 & 0.55 & 0.39 \\
\hline 0.42 & 1.00 & 0.74 \\
\hline
\end{tabular}


Pretest score, posttest and N-gain for student learning outcomes in control and experimental classes are shown in Fig. 2.

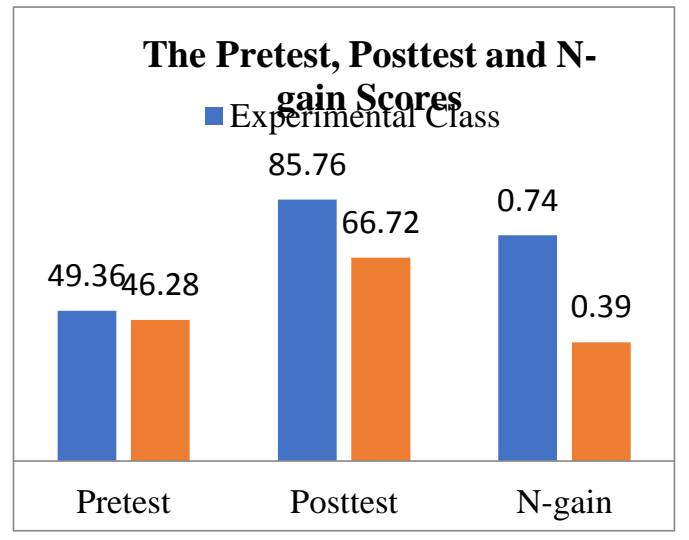

Fig. 2. The Pretest, Posttest, and N-gain Scores in Experimental and Control Class Groups

Based on Table 4 and Fig. 2, it can be seen that the average score of pretest and posttest in the control class and experiment class is not much different, where the average pretest score is 49.36 experiment class and 46.28 control class. Posttest results as presented in Graphic 2 can be seen that the average posttest score of the experimental class is higher than the control class that is 85.76 and 66.72 control classes. The $\mathrm{N}$-gain values were averaged at 0.74 (high criteria) of the experimental class and 0.39 (moderate criteria) of the control class.

The increase of pretest learning result score to posttest is significant in both the control and experiment classes because the given test has an equation that is in the form of multiple choice. The following example of pretest and posttest is presented in Fig. 3. below.
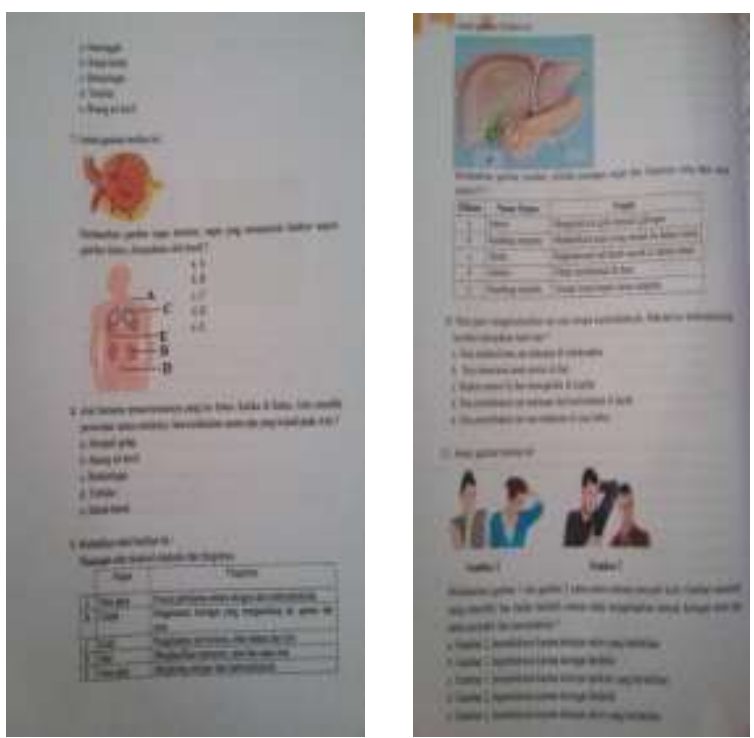

(a)

(b)

Fig. 3. Examples of Pretest Problems (a) and Posttest Problems (b)

Based on Fig. 3, a pretest question (a) was given the day before the study was conducted, consisting of 30 multiplechoice questions of general excretory material to measure the ability of control class students and experimental class how they understood the material of excretory system in general. The posttest (b) problem was given the day after the study, in which 30 multiple-choice questions of the excretory system material were in-depth to measure the ability of the controlclass students and the experimental class on how they understood the material of the excretory system in depth. Both of these multiple-choice questions have difficulty level problems that have been adapted to the standards for senior high school, consisting of C2, C3, C4, and C5 levels. The reason for not using $\mathrm{C} 1$ level is because the standard for high school students is too easy and not up to level C6 because it is created while for the choice of multiple choice options are available and more appropriate to use for the material essay. The level matter has been adjusted with Taxonomy Bloom that has been revised in the realm of cognitive knowledge.

\section{DISCUSSION}

The inquiry-based learning module on excretory material significantly improves student learning outcomes. The increased posttest learning outcomes evidence the effectiveness of the inquiry-based learning module after learning by using modules. Student learning outcomes increased from pretest to posttest calculated by the $\mathrm{N}$-gain value as presented in Table 4, obtained by 0.74 included in the higher criteria in the experimental class higher than the control class of 0.39 in the average criteria.

Modules used as teaching materials and proper learning methods can improve learning outcomes are also well viewed regarding the learning process and learning outcomes [19]. At the educational level, the use of teaching modules should be widely used to improve student learning outcomes [20]. Learning through inquiry-based learning can shape and develop self-concept in students so that they can understand basic concepts and ideas better and encourage students to think and work on their initiatives to improve learning outcomes [21]. The experimental class learning outcomes increased at each meeting and showed average results tended to be higher than the control class learning outcomes as presented in Fig. 1. It was supported by Abdi's study [22] which stated that there were significant differences in student learning outcomes between the experimental classes taught by inquiry learning received higher scores than the control 
classes taught by conventional learning. Inquiry-based learning can not only improve the learning outcomes (cognitive) but can improve the psychomotor attitude and skill, because the learning of inquiry-based learning is centered on the students, the teacher is only as the facilitator who helps the students [23].

Based on the results of activities in the module presented in Fig. 1, shows that the activities undertaken by students using inquiry-based learning syntax can improve student learning outcomes. Learning uses inquiry-based learning may be more effective in helping students acquire scientific process skills in science learning. When students engage in inquiry, students describe objects and events, ask questions, make explanations, test explanations of scientific knowledge and communicate their opinions with others, in this way students actively develop their understanding of science by combining scientific knowledge with reasoning and thinking skills [24]. Besides, by using the right learning one of the inquiry-based learning in the learning process can improve learning outcomes as the goal of learning. Inquiry-based learning can be trained in improving critical thinking skills through teaching and learning and developing knowledge, skills and assessing the learning outcomes necessary to achieve success in the information age [25].

The inquiry-based learning module that is used in the learning process can improve student learning outcomes because in the module presented activities that are structured in the form of practicum and observation by using the syntax of inquiry-based learning. The inquiry-based learning module contains learning activities that encourage students to analyze, solve problems based on facts found and designed to gain students' conceptual understanding [26]. Student learning response to learning with inquiry-based learning model is very influential on the success in achieving the learning objectives, one of the student learning outcomes increased as well as the behavior of students more active in learning [27]. It is supported by research [28] which states that the inquiry-based learning model can improve learning outcomes by directing students to explore and help students build knowledge through real-world problem-solving.

Overall, based on the results of the analysis has shown that the use of inquiry-based learning module on excretory system material is more effective in improving student learning outcomes. Lile \& Bran [29] stated that many factors that influence the excellent learning outcomes for students, one of them is the problem given to train students to think how to answer the questions given so that students are encouraged to get good grades for themselves. The given question refers to taxonomy bloom due to it is accurate in measuring students' ability to understand level-level questions from $\mathrm{C} 2-\mathrm{C} 5$, developing student learning outcomes and question-making instruments and easily understood appraisals for teachers [30]. Good learning outcomes do not only change in the cognitive domain but also in the affective and psychomotor spheres of students, so students can appreciate that learning outcomes are obtained through the learning process [31].

\section{CONCLUSION}

Inquiry-based learning module is effective learning to improve student cognitive learning outcomes because the results of statistical analysis test showed there are significant differences between control classes taught by using modules made by biology teachers in Surakarta get scores that obtained at 0.390 (middle) and 0.749 (high) experimental classes taught by using inquiry-based learning module on excretory system material.

\section{ACKNOWLEDGMENT}

The researchers would like to express their gratitude especially to the students of State Senior High School in Surakarta as well as the teachers and all those who have assisted this research.

\section{REFERENCES}

[1] Widowati, A. Diktat Pendidikan Sains. Yogyakarta : Fakultas Matematika dan Ilmu Pengetahuan Alam Universitas Yogyakarta, 2008 .

[2] Turiman, P., Omar, J., Daud, M., Adzliana and Osman, K, "Fostering the $21^{\text {st }}$ Century Skills Through Scientific Literacy and Science Process Skills". Procedia Social and Behavioral Sciences, vol 59, pp 110-116, 2011.

[3] Silva, E. Measuring Skills for the $21^{\text {st }}$ Century. Washington D.C :Education Sector, 2008.

[4] PISA. Average Scores of 15-Year-Old Students on PISA Science Literacy Scale, by Education System. Retrieved August 01, 2017, from https://nces.ed.gov/survey/pisa/pisa2017/pisa2017highlights_42_asp.

[5] TIMSS. Trends International in Mathematics and Science Study. $\begin{array}{llll}\text { Retrieved August } & \text { 01, 2017, from }\end{array}$ http://nces.ed.gov/timss/figure11_8.asp.

[6] Witleni, M., Risdawati, R., and S, M. Pengaruh Faktor Internal dan Eksternal terhadap Hasil Belajar Biologi Siswa IPA di SMA N 1 Linggo Sari Baganti Kabupaten Pesisir Selatan. Padang : STKIP PGRI Sumatera Barat, 2012.

[7] Kleebbua, C., and Siriparp, T. "Effects of Education and Attitude on Essential Learning Outcomes". Procedia Social and Behavioral Sciences 217, pp 941-949, 2016.

[8] Andrini, S. Vera. "The Effectiveness of Inquiry Learning Method to Enhance Student's Learning Outcome: A Theoretical and Empirical Review". Journal of Educational and Practice, ISSN 2222-288X, vol 7 (3), 2016.

[9] Mane, A., and Surdin. "Faktor-Faktor Penyebab Rendahnya Hasil Belajar Siswa pada Mata Pelajaran Geografi Di SMA Negeri 1 Mawasangka”. Jurnal Penelitian Pendidikan Geografi, vol. 1 (1), 2016.

[10] Thoharudin, U., Hendrawati, S., and Rustaman, A. Membangun Literasi Sains Peserta Didik. Bandung : Humaniora, 2011.

[11] Sukiman. Pengembangan Media Pembelajaran. Yogyakarta : Pustaka Insan Madani, 2012.

[12] Suardana, I. N. Penerapan Strategi Pembelajaran Berbasis Masalah dengan Pendekatan Kooperatif Berbantuan Modul untuk Meningkatkan Kualitas Proses dan Hasil Belajar Mahasiswa pada Perkuliahan Kimia Fisika 1. Singaraja : IKIP Negeri Singaraja, 2010.

[13] Kemendikbud. Konsep dan Implementasi Kurikulum 2013. Retrieved September 23, 2016, from http://litbang.kemendikbud.go.id/ndex.php/index.berita.kurikulum/24 3-kurikulum-2013-pergeseran-paradigma-belajar-abad-21, 2014.

[14] Pedaste, M., Maeots, M., Siiman, A. L., Riesen, A. N. S., Kamp, T. E., Manoli, C. C., et al. "Phases of Inquiry-Based Learning: Definitions and The Inquiry Cycle". Educational Research Review, vol 14, pp 4761, 2015.

[15] Unver, O. A., and Arabacioglu, S. "Overviews on Inquiry-Based and Problem Based Learning Methods". Western Anatolia Journal of Educational Sciences. Turkey ISSN 1308-8971, 2011. 
[16] Thaiposri, P., and Wannapiroon, P. "Enhancing Students' Critical Thinking Skills through Teaching and Learning by Inquiry-Based Learning Activities using Social Network and Cloud Computing". Procedia Social and Behavioral Sciences 174, 2015, pp 2137-2144.

[17] Widiyanto, J. SPSS For Windows. Surakarta: Laboratorium FKIP UMS, 2010.

[18] Pedaste, M., Maeots, M., Siiman, A. L., Riesen, A. N. S., Kamp, T. E., Manoli, C. C., et al. "Phases of Inquiry-Based Learning: Definitions and The Inquiry Cycle". Educational Research Review, Vol. 14; 47-61, 2015.

[19] Ikmah, S. T. "Efektivitas Penerapan Model Pembelajaran TAI (Team Assisted Individualization) berbantuan Modul Pembelajaran terhadap Hasil Belajar Ekonomi”. Economic Education Analysis Journal, EEJI, vol 1, 2012.

[20] Kulldel, N. "Authentic Teaching and Learning through Synthetic Biology". Journal of Biological Engineering vol 1 (8), pp 1-6, 2007.

[21] Wardani, A. "Pengaruh Pendekatan Inquiry Based Learning terhadap Hasil Belajar Kimia". Jurnal Kependidikan Kimia "Hydrogen", ISSN 2338-6480, vol 1 (1), 2013.

[22] Abdi, A. "The Effect of Inquiry-Based Learning Method on Students' Academic Achievement in Science Course". Universal Journal of Educational Research, DOI: 10.13189/ujer.2014.020104, vol 2 (1), 2014.

[23] Andrini, S. Vera. "The Effectiveness of Inquiry Learning Method to Enhance Student's Learning Outcome: A Theoretical and Empirical Review". Journal of Educational and Practice, ISSN 2222-288X, vol 7 (3), 2016.

[24] Simsek, P., and Kabapinar, F. "The Effects of Inquiry-Based Learning on Elementary Students' Conceptual Understanding of Matter, Scientific Process Skills, and Science Attitudes". Procedia Social and Behavioral Sciences 2, pp 1190-1194, 2010.

[25] Thaiposri, P., and Wannapiroon, P. "Enhancing Students' Critical Thinking Skills through Teaching and Learning by Inquiry-Based Learning Activities using Social Network and Cloud Computing". Procedia Social and Behavioral Sciences 174, 2015, pp 2137-2144.

[26] Ikhsan, M., Sutarno., dan Prayitno, A. B. "Pengembangan Modul Berbasis Inkuiri Terbimbing pada Materi Sistem Gerak Manusia untuk Meningkatkan Hasil Belajar Siswa Kelas XI MIA SMA Negeri 1 Wera Kabupaten Bima Nysa Tenggara Barat”. Jurnal Inkuiri, ISSN 22527893, vol 5 (1), 2016.

[27] Kusmaryono, H., dan Setiawati, R. "Penerapan Inquiry Based Learning untuk Mengetahui Respon Belajar Siswa pada Materi Konsep dan Pengelolaan Koperasi”. Jurnal Pendidikan Ekonomi Dinamika Pendidikan, vol 8 (2), pp 133-145, 2013.

[28] Panasaran, M., and Nuangchalerm, P. "Learning Outcomes of Project Based and Inquiry-Based Learning Activities". Journal of Social Sciences, vol 6 (2), ISSN 1549-3652, 2010.

[29] Lile, R., and Bran, C. "The Assessment of Learning Outcomes". Procedia Social and Behavioral Sciences 163, 2014, pp 125-131.

[30] IACBE. Bloom's Taxonomy of Educational Objectives and Writing Intended Learning Outcomes Statements. USA, 2014.

[31] Aziz, A. A., Yusof, M, K., and Yatim, M. J. "Evaluation of the Effectiveness of Learning Outcomes from Students' Perspectives". Procedia Social and Behavioral Sciencess 56, 2012, pp 22-30. 